\title{
A Meroisoprenoid, Heptenolides, and C-Benzylated Flavonoids from Sphaerocoryne gracilis ssp. gracilis
}

Gasper Maeda, Joan J. E. Munissi, Sofia Lindblad, Sandra Duffy, Jerry Pelletier, Vicky M. Avery, Stephen S. Nyandoro,* and Máté Erdélyi*

Cite This: J. Nat. Prod. 2020, 83, 316-322

Read Online

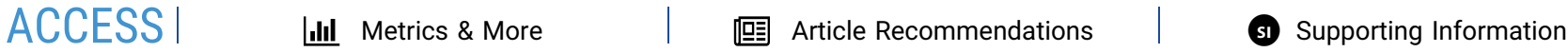

ABSTRACT: A new meroisoprenoid (1), two heptenolides (2 and 3), two $C$-benzylated flavonoids (4 and 5), and 11 known compounds (6-16) were isolated from leaf, stem bark, and root bark extracts of Sphaerocoryne gracilis ssp. gracilis by chromatographic separation. The structures of the new metabolites 1-5 were established by NMR, IR, and UV spectroscopic and mass spectrometric data analysis. (Z)-Sphaerodiol (7), (Z)-acetylmelodorinol (8), 7-hydroxy-6-hydromelodienone (10), and dichamanetin (15) inhibited the proliferation of Plasmodium falciparum (3D7, Dd2) with $\mathrm{IC}_{50}$ values of $1.4-10.5 \mu \mathrm{M}$, although these compounds also showed cytotoxicity against human embryonic kidney HEK-293 cells. None of the compounds exhibited significant disruption in protein translation when assayed in vitro.

$\mathrm{T}^{\mathrm{k}}$ he genus Sphaerocoryne (Annonaceae), formerly known as Melodorum, consists of the three species S. fruticosum, S. gracilis (ssp. engleriana and gracilis), and S. punctulatum. It is represented by $S$. gracilis ssp. engleriana, native to Angola, the Democratic Republic of Congo, and Zambia, in western Africa, while $S$. gracilis ssp. gracilis is confined to Kenya, Mozambique, and Tanzania, in eastern Africa. In Tanzania, S. gracilis ssp. gracilis (Engl. \& Diels) Verdc. is reported to grow in a few fragmented localities, including forest reserves in the Eastern Arc Mountains and in the Coastal Forests. ${ }^{1,2}$ Previous phytochemical studies of the genus revealed the presence of aporphine alkaloids in S. punctulatum (formerly Melodorum punctulatum), a small rain-forest tree endemic to New Caledonia (a French archipelago in the Southwest Pacific Ocean). ${ }^{3}$ Further studies revealed that S. fruticosum ( $M$. fruticosum), a species native to Southeast Asia, contains novel antitumor heptenolides. ${ }^{4-6}$ Phytochemical investigation of the Tanzanian Sphaerocoryne species also yielded heptenolides together with polyhydroxylated C-benzyl flavanones. ${ }^{7,8}$ The structures of some of the polyhydroxylated $C$-benzyl flavonoids have not been fully described, and nor have their bioactivities been reported. ${ }^{7,8}$ As part of our continued efforts in the search for bioactive metabolites from Tanzanian flora, S. gracilis spp. gracilis was reinvestigated regarding its activity against the malaria pathogen Plasmodium falciparum and also for cytotoxicity using the human embryonic kidney cell (HEK293) assay. Some of the isolated metabolites were also screened for their potential translational inhibitory activity by monitoring both cap-dependent and independent translation. ${ }^{9,10}$

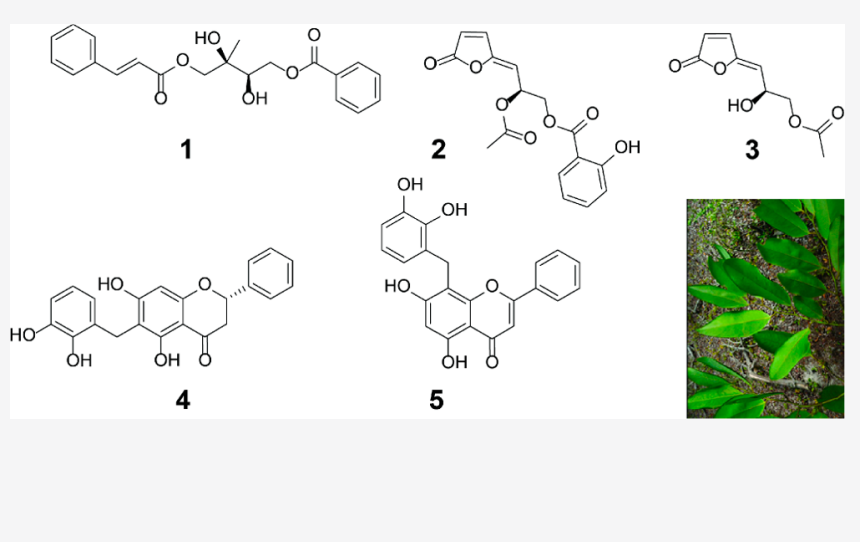

\section{RESULTS AND DISCUSSION}

Repeated silica gel column chromatography of the methanolic extracts of the stem and root barks and leaves of Sphaerocoryne gracilis spp. gracilis, followed by gel filtration on Sephadex LH20 and further purification on HPLC, gave five new metabolites (1-5) and 11 known compounds (6-16, Figure S1, Supporting Information). The structures of the new meroisoprenoid (1), two heptenolides (2 and 3), and two $C$ benzylated flavonoids (4 and 5) were established using NMR spectroscopic and mass spectrometric techniques. The identities of the known compounds $3^{\prime \prime}$-hydroxygracinol (6), $(Z)$-sphaerodiol $(7),{ }^{11,12}(Z)$-acetylmelodorinol (8), ${ }^{10,11,13}$ (Z)-melodorinol (9), ${ }^{10-12}$ 7-hydroxy-6-hydromelodienone (10), ${ }^{4}$ pinocembrin $(\mathbf{1 1}),{ }^{11,14} 5,7$-dihydroxyflavone $(\mathbf{1 2}){ }^{15}$ chamanetin (13), ${ }^{16}$ isochamanetin $(14),{ }^{16}$ dichamanetin (15), ${ }^{16}$ and polycarpol $(\mathbf{1 6})^{16}$ were confirmed by comparing their spectroscopic data with those previously reported.

Compound 1 was obtained as a colorless oil and was assigned the molecular formula $\mathrm{C}_{21} \mathrm{H}_{23} \mathrm{O}_{6}$ based on HRESIMS (Figure S9, Supporting Information) and NMR data (Table 1, Figures S2-S8, Supporting Information). Its UV spectrum showed absorptions at $\lambda_{\max } 215,230$, and $275 \mathrm{~nm}$, consistent with a conjugated $\pi$-system encompassing a benzene ring,

Received: July 30, 2019

Published: February 18, 2020 


\section{Chart 1}

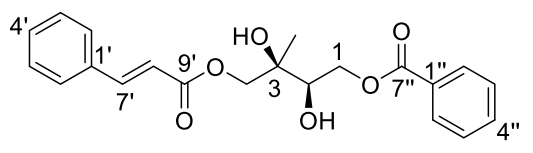

1

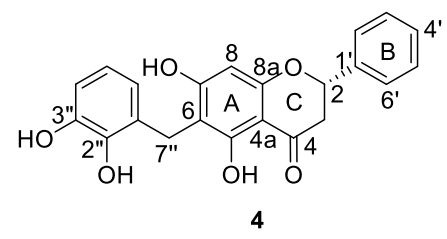

Table 1. NMR Spectroscopic Data $\left({ }^{1} \mathrm{H}\right.$ at $800 \mathrm{MHz},{ }^{13} \mathrm{C}$ at $200 \mathrm{MHz}, \mathrm{CDCl}_{3}$ ) of Gracidiol (1)

\begin{tabular}{|c|c|c|c|c|}
\hline position & $\delta_{\mathrm{C}}$, type & $\delta_{\mathrm{H}}$ & $J(\mathrm{~Hz})$ & $\mathrm{HMBC}, \mathrm{H} \rightarrow \mathrm{C}$ \\
\hline \multirow[t]{2}{*}{1} & $66.3, \mathrm{H}_{2} \mathrm{C}-\mathrm{O}$ & 4.69 & $\begin{array}{l}\text { dd }(11.8, \\
2.8)\end{array}$ & $\mathrm{C}-7^{\prime \prime}$ \\
\hline & & 4.47 & $\begin{array}{l}\text { dd }(11.8, \\
7.8)\end{array}$ & $\mathrm{C}-2, \mathrm{C}-3, \mathrm{C}-7^{\prime \prime}$ \\
\hline 2 & 73.6, $\mathrm{HC}-\mathrm{O}$ & 3.96 & $\begin{array}{l}\text { dd }(7.8, \\
2.8)\end{array}$ & $\begin{array}{l}\mathrm{C}-1, \mathrm{C}-3, \mathrm{C}-4, \\
\mathrm{CH}_{3}-3\end{array}$ \\
\hline $\mathrm{OH}-2 / 3$ & & 3.49 & s & \\
\hline 3 & $73.4, \mathrm{C}-\mathrm{O}$ & & & \\
\hline $\mathrm{CH}_{3}-3$ & 20.0, $\mathrm{CH}_{3}$ & 1.34 & $\mathrm{~s}$ & C-2, C-4 \\
\hline \multirow[t]{2}{*}{4} & $68.9, \mathrm{H}_{2} \mathrm{C}-\mathrm{O}$ & 4.48 & $\mathrm{~d}(11.5)$ & $\begin{array}{l}\mathrm{C}-2, \mathrm{C}-3, \mathrm{CH}_{3}-3, \mathrm{C}- \\
9^{\prime}\end{array}$ \\
\hline & & 4.20 & $\mathrm{~d}(11.5)$ & $\begin{array}{l}\mathrm{C}-2, \mathrm{C}-3, \mathrm{CH}_{3}-3, \mathrm{C}- \\
9^{\prime}\end{array}$ \\
\hline $1^{\prime}$ & $134.2, \mathrm{C}$ & & & \\
\hline $2^{\prime} / 6^{\prime}$ & $128.4, \mathrm{CH}$ & 7.54 & $\mathrm{~m}$ & $\mathrm{C}-3^{\prime} / 5^{\prime}, \mathrm{C}-4^{\prime}, \mathrm{C}-7^{\prime}$ \\
\hline $3^{\prime} / 5^{\prime}$ & $\begin{array}{c}129.1 / 130.8 \\
\mathrm{CH}\end{array}$ & $\begin{array}{r}7.39- \\
7.40^{a}\end{array}$ & $\mathrm{~m}$ & $\mathrm{C}-1^{\prime}, \mathrm{C}-2^{\prime} / 6^{\prime}$ \\
\hline $4^{\prime}$ & $\begin{array}{c}\text { 130.8/129.1 } \\
\mathrm{CH}\end{array}$ & $\begin{array}{l}7.39- \\
7.40^{a}\end{array}$ & $\mathrm{~m}$ & $\mathrm{C}-2^{\prime} / 6^{\prime}$ \\
\hline $7^{\prime}$ & 146.4, CH & 7.75 & $\mathrm{~d}(16.0)$ & $\begin{array}{l}\mathrm{C}-1^{\prime}, \mathrm{C}-2^{\prime} / 6^{\prime}, \mathrm{C}-8^{\prime}, \\
\mathrm{C}-9^{\prime}\end{array}$ \\
\hline $8^{\prime}$ & 117.2, $\mathrm{CH}$ & 6.47 & $\mathrm{~d}(16.0)$ & $\mathrm{C}-1^{\prime}, \mathrm{C}-7^{\prime}, \mathrm{C}-9^{\prime}$ \\
\hline $9^{\prime}$ & 167.6, $\mathrm{C}=\mathrm{O}$ & & & \\
\hline $1^{\prime \prime}$ & 134.2, C & & & \\
\hline $2^{\prime \prime} / 6^{\prime \prime}$ & $129.9, \mathrm{CH}$ & 8.05 & $\mathrm{~m}$ & C-4", C-7" \\
\hline $3^{\prime \prime} / 5^{\prime \prime}$ & $128.6, \mathrm{CH}$ & 7.45 & $\mathrm{~m}$ & $\mathrm{C}-2^{\prime \prime} / 6^{\prime \prime}, \mathrm{C}-4^{\prime \prime}$ \\
\hline $4^{\prime \prime}$ & 133.4, CH & 7.56 & $\mathrm{~m}$ & $\mathrm{C}-2^{\prime \prime} / 6^{\prime \prime}$ \\
\hline $7^{\prime \prime}$ & $167.3, \mathrm{C}=\mathrm{O}$ & & & \\
\hline
\end{tabular}

whereas its IR spectrum indicated $\mathrm{O}-\mathrm{H}\left(3424 \mathrm{~cm}^{-1}\right), \mathrm{C}=\mathrm{C} /$ $\mathrm{C}=\mathrm{O}\left(1641 \mathrm{~cm}^{-1}\right)$, and $\mathrm{C}-\mathrm{O}\left(1265 \mathrm{~cm}^{-1}\right)$ stretches. ${ }^{11,16}$ The NMR data (Table 1, Figures S2 and S3, Supporting Information) suggested $\mathbf{1}$ to have two carbonyl functionalities, two aromatic systems, and four oxygen-substituted aliphatic groups. The NMR spectra showed characteristic signals for a benzoyloxy moiety, that is $\mathrm{H}-2 " / 6^{\prime \prime}\left(\delta_{\mathrm{H}} 8.05, \delta_{\mathrm{C}} 129.6\right), \mathrm{H}-3^{\prime \prime} /$ $5^{\prime \prime}\left(\delta_{\mathrm{H}} 7.45, \delta_{\mathrm{C}} 128.6\right)$, and $\mathrm{H}-4^{\prime \prime}\left(\delta_{\mathrm{H}} 7.56, \delta_{\mathrm{C}} 133.4\right)$. In addition, the ${ }^{1} \mathrm{H}$ NMR spectrum indicated the presence of trans-disposed olefinic protons at $\delta_{\mathrm{H}} 7.75$ and $\delta_{\mathrm{H}} 6.47(\mathrm{~J}=16.0$ $\mathrm{Hz}$ ) with chemical shifts compatible with an $\alpha, \beta$-unsaturated carbonyl system. Based on HMBC correlations (Table 1, Figure S7, Supporting Information) these were established as being part of a cinnamoyl moiety. Thus, the $\beta$-proton $\left(\delta_{\mathrm{H}}\right.$ 7.75) showed ${ }^{3} J_{\mathrm{H}, \mathrm{C}}$ HMBC correlations with the aromatic carbons C-2'/6' $\left(\delta_{\mathrm{C}} 129.9\right)$ and the carbonyl carbon C-9' $\left(\delta_{\mathrm{C}}\right.$ 167.6) of the cinnamoyl moiety. The aromatic proton signals at $\delta_{\mathrm{H}} 7.39-7.40$ were assigned to $\mathrm{H}-3^{\prime} / 5^{\prime}$ and $\mathrm{H}-4^{\prime}$, while the signal at $\delta_{\mathrm{H}} 7.54$ to $\mathrm{H}-2^{\prime} / 6^{\prime}$. Moreover, the HSQC spectrum (Figure S6, Supporting Information) indicated two sets of oxymethylene units with diastereotopic protons. One of these was part of an $\mathrm{ABX}$ spin system (COSY) encompassing protons $\mathrm{H}-1 \mathrm{a}\left(\delta_{\mathrm{H}} 4.69\right), \mathrm{H}-1 \mathrm{~b}\left(\delta_{\mathrm{H}} 4.47\right)$, and $\mathrm{H}-2\left(\delta_{\mathrm{H}} 3.96\right)$. These diastereotopic protons gave HMBC cross-peaks to C-7" $\left(\delta_{\mathrm{C}} 167.3\right)$ and were hence linked to the benzoyloxy unit. The second set of diastereotopic protons $\mathrm{H}-4 \mathrm{a}\left(\delta_{\mathrm{H}} 4.48\right)$ and $\mathrm{H}-4 \mathrm{~b}$ $\left(\delta_{\mathrm{H}} 4.20\right)$ showed only a geminal coupling, ${ }^{2} J=11.5 \mathrm{~Hz}$, and were shown to be linked to the oxygenated quaternary carbon C-3 $\left(\delta_{\mathrm{C}} 73.4\right)$ on one side and to the cinnamoyl unit on the other, as indicated by their HMBC cross-peaks to C-2 $\left(\delta_{\mathrm{C}}\right.$ 73.6), C-3 $\left(\delta_{\mathrm{C}} 73.4\right)$, and C-9' $\left(\delta_{\mathrm{C}} 167.6\right)$. The position of $\mathrm{CH}_{3}-3\left(\delta_{\mathrm{H}} 1.34 ; \delta_{\mathrm{C}} 20.0\right)$ was deduced based on its HMBC cross-peak to the oxy-quaternary chiral carbon C-3 $\left(\delta_{\mathrm{C}} 73.4\right)$. Hence, compound $\mathbf{1}$ was concluded to be constituted by an isoprenoyl unit attached to a cinnamoyl unit on one end and a benzoyloxy moiety on the other end.

The relative configurations of C-2 $\left(\delta_{\mathrm{C}} 73.6\right)$ and C-3 $\left(\delta_{\mathrm{C}}\right.$ 73.4) might be indicated by the NOESY correlation (Figure S5, Supporting Information) of $\mathrm{CH}_{3}-3\left(\delta_{\mathrm{H}} 1.34\right)$ with oxymethine proton $\mathrm{H}-2\left(\delta_{\mathrm{H}} 3.96\right)$, suggesting the erythro relationship of the hydoxy groups at C-2 and C-3. As the C-2$\mathrm{C}-3$ bond freely rotates, the determination of the relative configuration of these carbons cannot be trusted and should be corroborated by other techniques. Based on the above spectroscopic evidence, however, this new natural product, gracidiol (1), isolated from the leaves of $S$. gracilis ssp. gracilis, was characterized as 4 -(cinnamoyloxy)- $2 \beta, 3 \beta$-dihydroxy- $3 \alpha$ methylbutyl benzoate. From the biogenesis point of view, the compound is envisaged to be a meroisoprenoid formed through both mevalonic and shikimate pathways. It is unprecedented in the genus Sphaerocoryne.

Compound 2 was obtained as a colorless oil. Its molecular formula was determined as $\mathrm{C}_{9} \mathrm{H}_{10} \mathrm{O}_{5}$ based on HRESIMS (Figure S17, Supporting Information) and NMR (Table 2) analyses. Its UV spectrum showed an absorption at $\lambda_{\max } 270$ $\mathrm{nm}$, consistent with a conjugated system. ${ }^{16}$ The broad IR absorption band at $3446 \mathrm{~cm}^{-1}$ is typical of a hydroxy functionality, whereas those at 1743 and $1781 \mathrm{~cm}^{-1}$ are compatible with the $\alpha, \beta$-unsaturated carbonyls of butenolides. ${ }^{11,16}$ The chemical shifts of the olefinic protons resonating at $\delta_{\mathrm{H}} 6.27(\mathrm{H}-2)$ and $\delta_{\mathrm{H}} 7.38(\mathrm{H}-3)$ were also consistent with an $\alpha, \beta$-unsaturated carbonyl moiety. The NMR spectroscopic 
Table 2. NMR Spectroscopic Data $\left({ }^{1} \mathrm{H}\right.$ at $800 \mathrm{MHz},{ }^{13} \mathrm{C}$ at $200 \mathrm{MHz}, \mathrm{CDCl}_{3}$ ) of 7-Acetylsphaerodol (2)

\begin{tabular}{|c|c|c|c|c|}
\hline position & $\delta_{\mathrm{C}}$, type & $\delta_{\mathrm{H}}$ & $J(\mathrm{~Hz})$ & $\mathrm{HMBC}, \mathrm{H} \rightarrow \mathrm{C}$ \\
\hline 1 & $168.9, \mathrm{C}=\mathrm{O}$ & & & \\
\hline 2 & 121.1, CH & 6.27 & $\mathrm{~d}(5.5)$ & C-1, C-3, C-4 \\
\hline 3 & 143.7, CH & 7.38 & $\mathrm{~d}(5.5)$ & C-1, C-2, C-4, C-5 \\
\hline 4 & $150.1, \mathrm{C}$ & & & \\
\hline 5 & $112.9, \mathrm{CH}$ & 5.33 & $\mathrm{~d}(8.0)$ & C-3, C-4, C-6, C-7 \\
\hline 6 & $65.9, \mathrm{C}-\mathrm{O}$ & 5.03 & $\begin{array}{l}\text { ddd, }(8.0,6.8, \\
3.8)\end{array}$ & C-4, C-5, C-7 \\
\hline \multirow[t]{2}{*}{7} & $67.2, \mathrm{H}_{2} \mathrm{C}-\mathrm{O}$ & 4.24 & $\mathrm{dd},(11.5,3.8)$ & $\begin{array}{c}\mathrm{C}-5, \mathrm{C}-6, \mathrm{O}-\mathrm{Ac}-7 \\
(\mathrm{C}=\mathrm{O})\end{array}$ \\
\hline & & 4.18 & $\mathrm{dd},(11.5,6.8)$ & $\begin{array}{l}\mathrm{C}-5, \mathrm{C}-6, \mathrm{OAc}-7 \\
(\mathrm{C}=\mathrm{O})\end{array}$ \\
\hline \multirow[t]{2}{*}{ OAc-7 } & 171.2, $\mathrm{C}=\mathrm{O}$ & & & \\
\hline & 20.9, $\mathrm{CH}_{3}$ & 2.11 & $s$ & OAc-7 $(\mathrm{C}=\mathrm{O})$ \\
\hline
\end{tabular}

data of 2 (Table 2, Figures S10-S16, Supporting Information) were diagnostic for a heptenolide moiety consisting of ABMX $\left[\delta_{\mathrm{H}} 4.24(\mathrm{H}-7 \mathrm{a}), \delta_{\mathrm{H}} 4.18(\mathrm{H}-7 \mathrm{~b}), \delta_{\mathrm{H}} 5.03(\mathrm{H}-6)\right.$, and $\delta_{\mathrm{H}} 5.33$ $(\mathrm{H}-5)]$ and $\alpha, \beta$-unsaturated $\left[\left(\delta_{\mathrm{H}} 7.38(\mathrm{H}-3)\right.\right.$ and $\delta_{\mathrm{H}} 6.27(\mathrm{H}-$ 2)] spin systems, resembling that of compound $7 .^{11,17}$ Comparison of its NMR data suggested 2 to be a close derivative of $(Z)$-sphaerodiol (7), with additional NMR signals observed at $\delta_{\mathrm{H}} 2.11$ and $\delta_{\mathrm{C}} 20.9$ and $\delta_{\mathrm{C}} 171.2$ (OAc-7), suggesting the presence of an additional acetyl group. The position of the acetyl moiety at C-7 was established from the HMBC (Table 2; Figure S16, Supporting Information) crosspeaks of the C-7 methylene protons $\left(\delta_{\mathrm{H}} 4.24\right.$ and $\left.\delta_{\mathrm{H}} 4.18\right)$ to $\delta_{\mathrm{C}} 171.2$ (OAc-7). NOESY correlations (Figure S14, Supporting Information) of H-3 $\left(\delta_{\mathrm{H}} 7.38\right)$ to $\mathrm{H}-5\left(\delta_{\mathrm{H}} 5.33\right)$ indicated the exocyclic double-bond geometry is $Z$. Its configuration at C-6 was the same as in compound 7, based on the comparable sign and magnitude of optical rotation. ${ }^{10,11}$ Based on the above evidence, the new compound (Z)-7acetylsphaerodol (2) was characterized as $(S, Z)$-2-hydroxy-3(5-oxofuran-2 $(5 \mathrm{H})$-ylidene)propyl acetate, the acetylated derivative of $(Z)$-sphaerodiol (7). ${ }^{11}$ Both compounds were obtained from the stem and the root bark methanol extracts of $S$. gracilis ssp. gracilis.

Compound 3 was obtained as a colorless oil and was assigned the molecular formula $\mathrm{C}_{16} \mathrm{H}_{15} \mathrm{O}_{7}$ based on analysis of its HRESIMS (Figure S25, Supporting Information) and NMR (Table 3, Figures S18-S24, Supporting Information) data. Its IR spectrum showed absorption bands at 3417 and $1639 \mathrm{~cm}^{-1}$, indicating the presence of $\mathrm{O}-\mathrm{H}$ and $\mathrm{C}=\mathrm{C}$ functionalities, respectively. ${ }^{16}$ The UV absorptions at $\lambda_{\max } 205$ and $240 \mathrm{~nm}$ along with the NMR data were compatible with the presence of a benzene moiety and an $\alpha, \beta$-unsaturated carbonyl system, which was corroborated by NMR (vide infra). ${ }^{16}$ The ${ }^{13} \mathrm{C}$ NMR spectrum (Table 3, Figure S19, Supporting Information) showed 16 signals, which were sorted with the aid of the HSQC spectrum (Figure S23, Supporting Information) into an oxymethine, an oxymethylene, an oxomethyl, three carbonyls, and $10 \mathrm{sp}^{2}$ carbons. Six $\mathrm{sp}^{2}$ carbons were assigned to an aromatic ring and four to two olefinic bonds (Table 3). The ${ }^{1} \mathrm{H}$ NMR spectrum of 3 (Table 3, Figure S18, Supporting Information) displayed signals at $\delta_{\mathrm{H}} 4.61(\mathrm{H}-7 \mathrm{a}), \delta_{\mathrm{H}} 4.55$ $(\mathrm{H}-7 \mathrm{~b}), \delta_{\mathrm{H}} 5.31(\mathrm{H}-5)$, and $\delta_{\mathrm{H}} 6.15(\mathrm{H}-6)$ corresponding to an ABMX spin system, as revealed by COSY and TOCSY spectra (Figures S20 and S22, Supporting Information), resembling that observed for compound 2. The chemical shifts of the olefinic protons $\delta_{\mathrm{H}} 6.30(\mathrm{H}-2)$ and $\delta_{\mathrm{H}} 7.38(\mathrm{H}-3)$ were also
Table 3. NMR Spectroscopic Data $\left({ }^{1} \mathrm{H}\right.$ at $800 \mathrm{MHz},{ }^{13} \mathrm{C}$ at $\left.200 \mathrm{MHz}, \mathrm{CDCl}_{3}\right)$ of $(\mathrm{Z})-2^{\prime}$-Hydroxyacetylmelodorinol (3)

\begin{tabular}{|c|c|c|c|c|}
\hline position & $\delta_{\mathrm{C}}$, type & $\delta_{\mathrm{H}}$ & $\mathrm{m}, J(\mathrm{~Hz})$ & $\mathrm{HMBC}, \mathrm{H} \rightarrow \mathrm{C}$ \\
\hline 1 & 168.5, $\mathrm{C}=\mathrm{O}$ & & & \\
\hline 2 & $121.9, \mathrm{CH}$ & 6.30 & $\mathrm{~d}(5.5)$ & C-1, C-3, C-4 \\
\hline 3 & $143.4, \mathrm{CH}$ & 7.38 & $\mathrm{~d}(5.5)$ & C-1, C-2, C-4 \\
\hline 4 & $150.9, \mathrm{C}$ & & & \\
\hline 5 & 108.6, CH & 5.31 & $\mathrm{~d}(7.9)$ & C-3, C-4, C-6, C-7 \\
\hline 6 & 67.2, $\mathrm{HC}-\mathrm{O}$ & 6.15 & $\begin{array}{l}\text { ddd, }(7.9,6.1, \\
3.9)\end{array}$ & $\begin{array}{l}\text { C-4, C-5, C-7, OAc-6 } \\
(\mathrm{C}=\mathrm{O})\end{array}$ \\
\hline \multirow[t]{2}{*}{ OAc-6 } & $169.9, \mathrm{C}=\mathrm{O}$ & & & \\
\hline & 21.0, $\mathrm{CH}_{3}$ & 2.11 & s & OAc-6 $(\mathrm{C}=\mathrm{O})$ \\
\hline \multirow[t]{3}{*}{7} & $65.0, \mathrm{H}_{2} \mathrm{C}-\mathrm{O}$ & 4.61 & $\begin{array}{l}\text { dd, (11.7, } \\
3.9)\end{array}$ & C-5, C-6, C-7' \\
\hline & & & & C5, C6, C-7' \\
\hline & & 4.55 & $\begin{array}{l}\mathrm{dd},(11.7, \\
6.1)\end{array}$ & C-5, C-6, C- $7^{\prime}$ \\
\hline $7^{\prime}$ & $169.7, \mathrm{C}=\mathrm{O}$ & & & \\
\hline $1^{\prime}$ & 112.0, C & & & \\
\hline $2^{\prime}$ & $161.9, \mathrm{C}-\mathrm{O}$ & & & \\
\hline $\mathrm{OH}-2^{\prime}$ & & 10.54 & $\mathrm{~s}$ & $\mathrm{C}-1^{\prime}, \mathrm{C}-2^{\prime}, \mathrm{C}-3^{\prime}$ \\
\hline $3^{\prime}$ & $117.9, \mathrm{CH}$ & 7.00 & $\mathrm{dd},(8.4,1.1)$ & $\mathrm{C}-1^{\prime}, \mathrm{C}-2^{\prime}, \mathrm{C}-5^{\prime}$ \\
\hline $4^{\prime}$ & $136.3, \mathrm{CH}$ & 7.48 & $\begin{array}{l}\text { ddd, }(8.4,7.2, \\
\quad 1.8)\end{array}$ & $\mathrm{C}-2^{\prime}, \mathrm{C}-6^{\prime}$ \\
\hline $5^{\prime}$ & 119.5, $\mathrm{CH}$ & 6.90 & $\begin{array}{l}\text { ddd, }(8.0,7.2 \text {, } \\
\quad 1.1)\end{array}$ & $\mathrm{C}-1^{\prime}, \mathrm{C}-3^{\prime}$ \\
\hline $6^{\prime}$ & 130.1, CH & 7.81 & $\mathrm{dd},(8.0,1.8)$ & $\mathrm{C}-2^{\prime}, \mathrm{C}-4^{\prime}, \mathrm{C}-7^{\prime}$ \\
\hline
\end{tabular}

similar to those of 2 and hence compatible with an $\alpha, \beta$ unsaturated carbonyl moiety. The above spectroscopic features are reminiscent of a butenolide system with an extension of an alicyclic three-carbon skeleton forming a heptenolide moiety, which has previously been reported for similar metabolites. $^{4-7,10,11}$ Overall, the NMR data of 3 resembled that of $(Z)$-acetylmelodorinol (8) and of related compounds ${ }^{4-7,10,11}$ with the only difference being the ortho-hydroxy group substitution of its benzoyloxy group. The placement of this hydroxy group functionality was established by the ABCD coupling pattern of the aromatic signals $\left({ }^{1} \mathrm{H}\right.$ NMR, COSY, and TOCSY) and by HMBC correlations (Table 2, Figure S24, Supporting Information). NOESY correlations (Figure S22, Supporting Information) of $\mathrm{H}-3\left(\delta_{\mathrm{H}} 7.38\right)$ and $\mathrm{H}-5\left(\delta_{\mathrm{H}} 5.31\right)$ revealed the $Z$-geometry of the exocyclic C-4, C-5 double bond, while the NOE of H-5 $\left(\delta_{\mathrm{H}} 5.31\right)$ and $\mathrm{H}-6\left(\delta_{\mathrm{H}} 6.15\right)$ might indicate the $\beta$-orientation of OAc- 6 . Whereas the latter assignment may be corroborated by the configuration of closely related compounds previously isolated from this genus, ${ }^{4-7,11,17}$ the C-5 to C-6 bond can freely rotate, making a purely NOE-based assignment unreliable. Nonetheless, the configuration of compound 3 was determined as being similar to those of $(Z)$-acetylmelodorinol (8) and ( $Z$ )-melodorinol (9), which were also isolated in the present study. The absolute configuration of the latter was recently determined by single-crystal X-ray diffraction analysis. ${ }^{10}$ Based on the above evidence, this new natural product, $(Z)-2^{\prime}$-hydroxyacetylmelodorinol (3), was characterized as (S,Z)-2-acetoxy-3-(5oxofuran-2 $(5 H)$-ylidene)propyl 2-hydroxybenzoate.

Compound 4 was obtained as a white powder and was assigned the molecular formula $\mathrm{C}_{22} \mathrm{H}_{19} \mathrm{O}_{6}$, based on the HRESIMS (Figure S33, Supporting Information) and NMR (Table 4) data. Its UV absorptions found at $\lambda_{\max } 210,290$, and $320 \mathrm{~nm}$ are diagnostic of dihydroflavones. ${ }^{18}$ The IR absorptions at 3430,1641 , and $1255 \mathrm{~cm}^{-1}$ corresponded to 
Table 4. NMR Spectroscopic Data $\left({ }^{1} \mathrm{H}\right.$ at $800 \mathrm{MHz},{ }^{13} \mathrm{C}$ at $200 \mathrm{MHz}, \mathrm{CDCl}_{3}$ ) for $3^{\prime \prime}$-Hydroxyisochamanetin (4)

\begin{tabular}{|c|c|c|c|c|}
\hline position & $\delta_{\mathrm{C}}$, type & $\delta_{\mathrm{H}}$ & $J(\mathrm{~Hz})$ & $\mathrm{HMBC}, \mathrm{H} \rightarrow \mathrm{C}$ \\
\hline 2 & 79.4, C-O & 5.38 & $\begin{array}{l}\text { dd, (13.1, } \\
2.8)\end{array}$ & $\begin{array}{l}\text { C-3, C- } 4, C-8 a, C-1^{\prime}, \\
\text { C- } 2^{\prime} / 6^{\prime}\end{array}$ \\
\hline \multirow[t]{2}{*}{3} & \multirow[t]{2}{*}{ 43.3, $\mathrm{CH}_{2}$} & 3.08 & $\begin{array}{l}\mathrm{dd},(17.2, \\
13.1)\end{array}$ & $\mathrm{C}-2, \mathrm{C}-4, \mathrm{C}-1^{\prime}$ \\
\hline & & 2.84 & $\begin{array}{l}\mathrm{dd},(17.2 \\
2.8)\end{array}$ & C-4a, C-4, C-1' \\
\hline 4 & 196.3, $\mathrm{C}=\mathrm{O}$ & & & \\
\hline $4 a$ & 103.1, C & & & \\
\hline 5 & $160.7, \mathrm{C}-\mathrm{O}$ & & & \\
\hline $\mathrm{OH}-5$ & & 12.89 & $\mathrm{~s}$ & C-5, C-6, C-4a \\
\hline 6 & 108.2, C & & & \\
\hline 7 & 163.0, C-O & & & \\
\hline 8 & $96.3, \mathrm{CH}$ & 6.03 & s & $\begin{array}{l}\text { C-4, C-4a, C-6, C-7, C- } \\
8 \mathrm{a}\end{array}$ \\
\hline $8 \mathrm{a}$ & 161.4, C-O & & & \\
\hline $1^{\prime}$ & 138.3, C & & & \\
\hline $2^{\prime} / 6^{\prime}$ & 126.3, $\mathrm{CH}$ & $7.42^{a}$ & $\mathrm{~m}$ & $\begin{array}{l}\mathrm{C}-2, \mathrm{C}-1^{\prime}, \mathrm{C}-2^{\prime} / 6^{\prime}, \mathrm{C}- \\
3^{\prime} / 5^{\prime}, \mathrm{C}-4^{\prime}\end{array}$ \\
\hline $3^{\prime} 5^{\prime}$ & 129.0, CH & $7.42^{a}$ & $\mathrm{~m}$ & $\begin{array}{l}\mathrm{C}-2, \mathrm{C}-1^{\prime}, \mathrm{C}-2^{\prime} / 6^{\prime}, \mathrm{C}- \\
3^{\prime} / 5^{\prime}, \mathrm{C}-4^{\prime}\end{array}$ \\
\hline $4^{\prime}$ & 129.1, CH & 7.38 & $\mathrm{~m}$ & $\mathrm{C}-1^{\prime}, \mathrm{C}-2^{\prime} / 6^{\prime}, \mathrm{C}-3^{\prime} / 5^{\prime}$ \\
\hline $1^{\prime \prime}$ & $126.8, \mathrm{C}$ & & & \\
\hline $2^{\prime \prime}$ & $141.2, \mathrm{C}-\mathrm{O}$ & & & \\
\hline $3^{\prime \prime}$ & $144.3, \mathrm{C}-\mathrm{O}$ & & & \\
\hline $4^{\prime \prime}$ & $113.2, \mathrm{CH}$ & $6.74^{a}$ & $\mathrm{~d}(4.8)$ & $\mathrm{C}-2^{\prime \prime}, \mathrm{C}-6^{\prime \prime}$ \\
\hline $5^{\prime \prime}$ & 123.1, $\mathrm{CH}$ & 7.05 & $\begin{array}{l}\mathrm{dd},(4.8 \\
4.8)\end{array}$ & $\mathrm{C}-1^{\prime \prime}, \mathrm{C}-3^{\prime \prime}, \mathrm{C}-4^{\prime \prime}, \mathrm{C}-6^{\prime \prime}$ \\
\hline $6^{\prime \prime}$ & 121.1, CH & $6.74^{a}$ & $\mathrm{~d}(4.8)$ & $\begin{array}{l}\mathrm{C}-1^{\prime \prime}, \mathrm{C}-2^{\prime \prime}, \mathrm{C}-4^{\prime \prime}, \mathrm{C}-5^{\prime \prime}, \\
\mathrm{C}-7^{\prime \prime}\end{array}$ \\
\hline $7^{\prime \prime}$ & 22.1, $\mathrm{CH}_{2}$ & 3.87 & $\mathrm{AB} d(14.5)$ & $\begin{array}{l}\text { C-7, C-6, C-5, C-1", C- } \\
2^{\prime \prime}, \mathrm{C}-6^{\prime \prime}\end{array}$ \\
\hline
\end{tabular}

${ }^{a}$ Overlapping signals.

$\mathrm{O}-\mathrm{H}, \mathrm{C}=\mathrm{C}$ aromatic, and $\mathrm{C}-\mathrm{O}$ stretches, respectively. ${ }^{18}$ The ${ }^{1} \mathrm{H}$ NMR spectrum (Table 4, Figure S26, Supporting Information) along with the COSY spectrum (Figure S28, Supporting Information) indicated an $\mathrm{ABX}$ coupling pattern for $\mathrm{H}-3 \alpha\left(\delta_{\mathrm{H}} 3.08\right), \mathrm{H}-3 \beta\left(\delta_{\mathrm{H}} 2.84\right)$, and $\mathrm{H}-2\left(\delta_{\mathrm{H}} 5.38\right)$, typical of the ring $\mathrm{C}$ of flavanones. ${ }^{17} \mathrm{An} \mathrm{AB}$ spin system integrating to two protons at $\delta 3.87$ was assigned to the benzyl methylene protons $\mathrm{H}-7^{\prime \prime}$ with the help of the HSQC experiment (Figure S30, Supporting Information). The signals at $\delta_{\mathrm{H}} 6.74$ (C-4" / $\left.\mathrm{C}-6^{\prime \prime}\right)$ and $\delta_{\mathrm{H}} 7.05$ (C-5") were deduced as belonging to aromatic protons of a dihydroxybenzyl group. The coupling pattern of the protons of the $C$-benzyl moiety supported the 2 - and $3^{\prime \prime}$-hydroxy groups as being ortho to each other. ${ }^{17,18}$ The linkage of the dihydroxybenzyl group at C-6 instead of C8 of the dihydroflavone moiety was deduced from the ${ }^{3} J_{\mathrm{CH}}$ HMBC of H-7" $\left(\delta_{\mathrm{H}} 3.87\right)$ to C-5 $\left(\delta_{\mathrm{C}} 160.7\right)$ (Table 4, Figure S31, Supporting Information). In turn, the singlet at $\delta_{\mathrm{H}} 6.03$ was assigned to $\mathrm{H}-8$ (instead of $\mathrm{C}-6$ as in 5). Moreover, HMBC cross-peaks of H-8 $\left(\delta_{\mathrm{H}} 6.03\right)$ and $\mathrm{H}-2\left(\delta_{\mathrm{H}} 5.38\right)$ to C$8 \mathrm{a}\left(\delta_{\mathrm{C}} 161.4\right)$ supported the placement of the dihydroxybenzyl moiety at C-6. The overlapping signals at $\delta_{\mathrm{H}} 7.42-7.43(4 \mathrm{H})$ were assigned to the ortho $\left(\mathrm{H}-2^{\prime} / 6^{\prime}\right)$ and meta $\left(\mathrm{H}-3^{\prime} / 5^{\prime}\right)$ protons, and that at $\delta_{\mathrm{H}} 7.38(1 \mathrm{H})$ to the para proton $\left(\mathrm{H}-4^{\prime}\right)$ of ring B. The signal at $\delta_{\mathrm{H}} 12.89$ signal was ascribed to OH-5, with its chemical shift being deshielded due to intramolecular hydrogen bonding with the nearby carbonyl group. The levorotatory specific rotation and the ECD spectrum (Experimental Section) of this flavonoid suggested the $S$ - configuration at C-2. ${ }^{19,20}$ Based on the features mentioned above, the new compound 3 "-hydroxyisochamanetin (4) was characterized as (S)-6-(2,3-dihydroxybenzyl)-5,7-dihydroxy-2phenylchroman-4-one, an isochamanetin derivative.

Compound $\mathbf{5}$ was obtained as a yellow powder. Its molecular formula, $\mathrm{C}_{22} \mathrm{H}_{17} \mathrm{O}_{6}$, was determined based on HRESIMS (Figure S40, Supporting Information) and NMR (Table 5)

Table 5. NMR Spectroscopic Data $\left({ }^{1} \mathrm{H}\right.$ at $800 \mathrm{MHz},{ }^{13} \mathrm{C}$ at $\left.200 \mathrm{MHz}, \mathrm{CD}_{3} \mathrm{OD}\right)$ of 2,3-Dehydro-3" -hydroxychamanetin (5)

\begin{tabular}{|c|c|c|c|c|}
\hline position & $\delta_{\mathrm{C}}$, type & $\delta_{\mathrm{H}}$ & $J(\mathrm{~Hz})$ & $\mathrm{HMBC}, \mathrm{H} \rightarrow \mathrm{C}$ \\
\hline 2 & $165.8, \mathrm{C}-\mathrm{O}$ & & & \\
\hline 3 & 105.6, $\mathrm{CH}$ & 6.69 & $\mathrm{~s}$ & C-2, C-4, C-4a, C-1' \\
\hline 4 & $184.3, \mathrm{C}=\mathrm{O}$ & & & \\
\hline $4 a$ & 105.7, C & & & \\
\hline 5 & $161.2, \mathrm{C}-\mathrm{O}$ & & & \\
\hline 6 & $99.9, \mathrm{CH}$ & 6.36 & $\mathrm{~s}$ & C-4, C-4a, C-5, C-7, C-8 \\
\hline 7 & 164.3, C-O & & & \\
\hline 8 & $107.4, \mathrm{C}$ & & & \\
\hline $8 \mathrm{a}$ & $157.0, \mathrm{C}-\mathrm{O}$ & & & \\
\hline $1^{\prime}$ & 132.6, C & & & \\
\hline $2^{\prime} / 6^{\prime}$ & 127.6, $\mathrm{CH}$ & 7.80 & $\mathrm{~m}$ & $\mathrm{C}-2, \mathrm{C}-2^{\prime} / 6^{\prime}, \mathrm{C}-4^{\prime}$ \\
\hline $3^{\prime} / 5^{\prime}$ & $130.2, \mathrm{CH}$ & 7.47 & $\mathrm{~m}$ & $\mathrm{C}-1^{\prime}, \mathrm{C}-2^{\prime} / 6^{\prime}, \mathrm{C}-3^{\prime} / 5^{\prime}$ \\
\hline $4^{\prime}$ & $132.9, \mathrm{CH}$ & 7.51 & $\mathrm{~m}$ & $\mathrm{C}-2^{\prime} / 6^{\prime}$ \\
\hline $1^{\prime \prime}$ & 128.3, C & & & \\
\hline $2^{\prime \prime}$ & 144.2, $\mathrm{C}-\mathrm{O}$ & & & \\
\hline $3^{\prime \prime}$ & 146.0, $\mathrm{C}-\mathrm{O}$ & & & \\
\hline $4^{\prime \prime}$ & $113.9, \mathrm{CH}$ & 6.62 & $\begin{array}{l}\mathrm{dd},(7.8, \\
1.6)\end{array}$ & C-2", C-3", C-5" C-6" \\
\hline $5^{\prime \prime}$ & $120.3, \mathrm{CH}$ & 6.47 & $\begin{array}{c}\text { dd, ( } 7.9 \\
7.8)\end{array}$ & $\mathrm{C}-1^{\prime \prime}, \mathrm{C}-3^{\prime \prime}, \mathrm{C}-4^{\prime \prime}, \mathrm{C}-6^{\prime \prime}$ \\
\hline $6^{\prime \prime}$ & $120.4, \mathrm{CH}$ & 6.34 & $\begin{array}{c}\text { dd, (7.9, } \\
1.6)\end{array}$ & $\mathrm{C}-2^{\prime \prime}, \mathrm{C}-4^{\prime \prime}, \mathrm{C}-7^{\prime \prime}$ \\
\hline $7^{\prime \prime}$ & 22.8, $\mathrm{CH}_{2}$ & 4.16 & s & $\begin{array}{l}\text { C-7, C-8, C-8a, C-1", C-2", } \\
\text { C-6" }\end{array}$ \\
\hline
\end{tabular}

data. The UV absorption at $\lambda_{\max } 280 \mathrm{~nm}$ was in agreement with a flavone, ${ }^{18}$ while the IR absorptions were consistent with hydroxy $\left(3430 \mathrm{~cm}^{-1}\right)$, aromatic $\left(1642 \mathrm{~cm}^{-1}\right)$, and C-O (1260 $\mathrm{cm}^{-1}$ ) stretches. ${ }^{15}$ The NMR spectroscopic data (Table 5, Figures S33-S39, Supporting Information) were comparable to those of 4, except the absence of an ABX spin system in the ${ }^{1} \mathrm{H}$ NMR spectrum for ring C. Instead, 5 showed a singlet at $\delta_{\mathrm{H}}$ 6.69 corresponding to the olefinic $\mathrm{H}-3$ of a flavone moiety. The ${ }^{3} J_{\mathrm{H}, \mathrm{C}}$ HMBC signals (Table 5, Figure S39, Supporting Information) of $\mathrm{H}^{\prime \prime} 7^{\prime \prime}\left(\delta_{\mathrm{H}} 4.16\right)$ to $\mathrm{C}-7$ and C-8a indicated a dihydroxybenzyl group to be substituted at position C-8, instead of C-6 as in compound 4. The 2D NMR data (Figures S35-S39, Supporting Information) of 5 showed resemblances to those of $\mathbf{4}$ and were in agreement with the established structure. Based on the above spectroscopic features, the new compound, 2,3-dehydro-3"-hydroxychamanetin (5), was characterized as 8-(2,3-dihydroxybenzyl)-5,7-dihydroxy-2-phenyl$4 H$-chromen-4-one.

Besides the new compounds 1-5, C-benzylated flavonoids $\mathbf{6}^{7}$ and $\mathbf{1 3 - 1 5},,^{15}$ heptenolides $7,{ }^{12} \mathbf{8},{ }^{13} \mathbf{9},{ }^{12}$ and $\mathbf{1 0},{ }^{4}$ flavonoids $\mathbf{1 1}{ }^{14}$ and $\mathbf{1 2},{ }^{15}$ and triterpenoid $16^{15}$ were also isolated and identified by comparison of their spectroscopic features to those previously published. The natural occurrence of heptenolides, such as $\mathbf{2 , 3}$, and 7-9, is limited so far only to the members of the Uvariae tribe within the family Annonaceae. ${ }^{10}$ Compounds 11 and $\mathbf{1 2}$ appear to be biogenetic 
precursors of 4-6 and 13-15. Flavonoids, such as 4-6 and 13-15, containing one or two hydroxylated $C$-benzyl groups on ring $\mathrm{A}$ as well as hydroxylated $C$-benzyl units that extend in a linear fashion, have been isolated from numerous species in the Annonaceae. ${ }^{8,18,21}$ Heptenolides $^{10-13}$ and $C$-benzylated flavonoids ${ }^{8,18,21,22}$ are known to possess diverse bioactivities.

As part of an ongoing search for bioactive phytochemicals, the compounds isolated from $S$. gracilis ssp. gracilis were screened for antiplasmodial activity against the chloroquinesensitive (3D7) and the chloroquine-resistant (Dd2) strains of P. falciparum. Compounds showing promising antiplasmodial activities, $<10 \mu \mathrm{M}$, were further screened for cytotoxicity using HEK-293 human embryonic kidney cells. Antiplasmodial activities of $\mathrm{IC}_{50} 1.4$ to $>40 \mu \mathrm{M}$ (Table 6), with 7-hydroxy-

Table 6. Antiplasmodial and Cytotoxic Activities of Compounds Isolated from Sphaerocoryne gracilis ssp. gracilis

\begin{tabular}{|c|c|c|c|c|}
\hline compound & $3 \mathrm{D} 7$ & $\mathrm{Dd} 2$ & HEK-293 & $\mathrm{SI}_{\mathrm{HEK} 293 / 3 \mathrm{D} 7}$ \\
\hline (Z)-sphaerodiol (7) & $10.5^{a}$ & NT & NT & \\
\hline $\begin{array}{l}(Z) \text {-acetylmelodorinol } \\
(\mathbf{8})\end{array}$ & $4.8^{a}$ & $6.7^{a}$ & $11.8^{a}$ & 3 \\
\hline$(Z)$-melodorinol (9) & $3.7^{a}$ & NT & NT & \\
\hline $\begin{array}{l}\text { 7-hydroxy-6- } \\
\text { hydromelodienone } \\
\text { (10) }\end{array}$ & $1.4^{a}$ & $4.1^{a}$ & $100 \%^{b}$ & \\
\hline dichamanetin (15) & $9.3^{a}$ & $6.7^{a}$ & $75 \%^{b}$ & \\
\hline pyrimethamine & 0.0025 & & 4.2 & 1688 \\
\hline chloroquine & 0.0045 & 0.046 & $60 \%^{b}$ & $>4000^{b}$ \\
\hline pyronaridine & 0.0036 & 0.0075 & 1.8 & 494.5 \\
\hline puromycin & 0.023 & 0.045 & 0.36 & 15.9 \\
\hline artesunate & 0.00048 & 0.00044 & $75 \%^{c}$ & $>22.000^{b}$ \\
\hline DHA & 0.00011 & 0.00015 & $50 \%^{c}$ & $>22.000^{b}$ \\
\hline
\end{tabular}

${ }^{a} \mathrm{IC}_{50} \cdot{ }^{b}$ Percentage growth inhibition at $40 \mu \mathrm{M}$. IA $=$ inactive at 40 $\mu \mathrm{M} . \mathrm{NT}=$ not tested. ${ }^{c}$ Percentage growth inhibition at $20 \mu \mathrm{M}$. The inhibitory activities are given as the mean value of at least two independent measurements. $\mathrm{IC}_{50}$ values were determined for one biological replicate in duplicate.

6-hydromelodienone (10) being the most active isolated constituent, were observed $\left[\mathrm{IC}_{50} 1.4(3 \mathrm{D} 7)\right.$ and $4.1 \mu \mathrm{M}$ $(\mathrm{Dd} 2)$ ]. However, 10 also showed cytotoxicity against HEK293 mammalian cells $(100 \%$ at $40 \mu \mathrm{M})$. (Z)-Acetylmelodorinol (8), melodorinol (9), and dichamanetin (15) showed low selectivities. Compounds 4, 5, and 12-14 inhibited plasmodial growth moderately (Table 6) at a $20 \mu \mathrm{M}$ concentration. All other compounds showed very weak or no antiplasmodial activities at $40 \mu \mathrm{M}$. The crude methanol extracts of the leaves, stem bark, and root bark of $S$. gracilis ssp. gracilis and the isolated 4, 5, 6, 9, 10, and 12 were tested further for the inhibition of cap-dependent and independent translation initiation using a luciferase model, ${ }^{17,23}$ but none showed significant translational inhibitory activity.

In conclusion, a new meroisoprenoid (1), two new heptenolides (2 and 3), two new C-benzylated flavonoids (4 and 5), and 11 known flavonoids, heptenolides and triterpenoids (6-16), were isolated from S. gracilis ssp. gracilis. The isolation of heptenolides from this plant is of significance, as these compounds have so far been reported to be restricted to the Uvariae tribe of the family Annonaceae. In line with previous reports, some of the isolated heptenolides and flavonoids (7-10 and 15, Table 6) showed antiplasmodial activities that may be interesting for drug development.

\section{EXPERIMENTAL SECTION}

General Experimental Procedures. Melting points were determined with a Büchi B-545 melting point instrument. The optical rotation and circular dichroism for compounds possessing chiral centers were determined using a 341LC OROT polarimeter $(589 \mathrm{~nm}$ temp $20.0^{\circ} \mathrm{C}$ ) and a JASCO J-715 spectrometer, respectively. The UV measurements were done using a 264 UV-vis spectrophotometer. A MIR 450FT-IR spectrometer was used to record the IR spectra. NMR spectra were acquired on a Bruker Avance III HD 800 NMR $\mathrm{MHz}$ spectrometer and analyzed with the software MestReNova (v10.0.0). Structural assignments were based on ${ }^{1} \mathrm{H}$ NMR, ${ }^{13} \mathrm{C}$ NMR, COSY, TOCSY, NOESY, HSQC, and HMBC spectra. LC-MS (ESI) spectra were acquired with a PerkinElmer PE SCIEX API 150 EX instrument equipped with a Turbolon spray ion source and a Gemini $5 \mathrm{~mm}$ RP-C18 $110 \AA$ column, using a gradient of $\mathrm{H}_{2} \mathrm{O}-\mathrm{CH}_{3} \mathrm{CN}(80: 20$ to $20: 80)$ in the presence of $0.2 \% \mathrm{HCO}_{2} \mathrm{H}$ and a separation time of $8 \mathrm{~min}$. HRESIMS were obtained with a Q-TOFLC/MS spectrometer with a lock mass ESI source (Stenhagen Analysis Lab AB, Gothenburg, Sweden), using a $2.1 \times 30 \mathrm{~mm} 1.7 \mu \mathrm{m}$ RP- $\mathrm{C}_{18}$ column and an elution gradient of $\mathrm{H}_{2} \mathrm{O}-\mathrm{CH}_{3} \mathrm{CN}$ (5:95 to 95:5, with $\left.0.2 \% \mathrm{HCO}_{2} \mathrm{H}\right)$. Analytical TLC was performed on aluminum plates precoated with silica gel 60 F254 (Merck). After development with an appropriate solvent system, the plates were evaluated under UV light (254 and $366 \mathrm{~nm}$ ) and then sprayed with 4anisaldehyde reagent, prepared by mixing $3.5 \mathrm{~mL}$ of 4-anisaldehyde with $2.5 \mathrm{~mL}$ of concentrated $\mathrm{H}_{2} \mathrm{SO}_{4}, 4 \mathrm{~mL}$ of glacial $\mathrm{HOAc}$, and 90 $\mathrm{mL}$ of $\mathrm{MeOH}$. The plates were then heated for the identification of UV-negative compounds and assessment of the color change of the UV-positive spots. Column chromatography was carried out using silica gel 60 (230-400 mesh), and gel filtration was performed over Sephadex LH-20 (Pharmacia) suspended in $\mathrm{CH}_{2} \mathrm{Cl}_{2}-\mathrm{MeOH}$ (1:1). Preparative HPLC was performed on a Waters 600E system using Chromulan software (Pikron Ltd.) and an $\mathrm{RP}_{-} \mathrm{C}_{8}$ Kromasil column $(250 \mathrm{~mm} \times 25 \mathrm{~mm})$ with a $\mathrm{H}_{2} \mathrm{O}-\mathrm{MeOH}$ gradient (70:30 to $\left.100: 0\right)$ for $20-40 \mathrm{~min}$ at a flow rate of $7 \mathrm{~mL} / \mathrm{min}$.

Plant Material. The stem bark, root bark, and leaves of Sphaerocoryne gracilis ssp. gracilis were collected in June 2014 from Pugu Forest Reserve, Kisarawe District, Pwani Region, Tanzania, at GPS location S $06^{\circ} 53^{\prime} 28.4^{\prime \prime}, \mathrm{E} 039^{\circ} 05^{\prime} 56.3^{\prime \prime}$ at an elevation of $269 \mathrm{~m}$. The plant was identified in the field and authenticated by Mr. F. M. Mbago, a senior taxonomist of the Herbarium, Botany Department of University of Dar es Salaam. The voucher specimen is deposited there with reference number FMM-3670.

Extraction and Isolation. Samples of the stem bark, root bark, and leaves were air-dried for 2 weeks and then pulverized to obtain about $2 \mathrm{~kg}$ of each. The materials were then separately soaked twice, consecutively, in methanol for $48 \mathrm{~h}$. The extracts were then filtered and concentrated in vacuo on a rotary evaporator, affording 70.0, 43.0, and $73.0 \mathrm{~g}$ of leaf, stem bark, and root bark extracts, respectively.

The leaf extract $(65.0 \mathrm{~g})$ was adsorbed on silica gel and subjected to gravity column chromatography with an elution gradient from $30 \%$ EtOAc- $i$-hexane to $10 \%$ EtOAc-methanol, to obtain 13 fractions of approximately $200 \mathrm{~mL}$ each. Fractions 4-6, obtained with 50\% EtOAc-i-hexane, were found to consist of the same components identified by TLC analysis. They were therefore combined and subjected to further gravitational column chromatography, using dry packing and elution with $30 \%$ EtOAc-i-hexane, resulting in 25 fractions of $\sim 80 \mathrm{~mL}$ each. TLC analysis enabled the combination of fractions 16-21, which were then subjected to separation on Sephadex, eluted with $1: 1 \mathrm{MeOH}-\mathrm{CH}_{2} \mathrm{Cl}_{2}$, to obtain 23 subfractions of $\sim 2 \mathrm{~mL}$ each. After TLC analysis, the combination of subfractions 7-10 gave $1.3 \mathrm{mg}$ of 5,7-dihydroxyflavone (12), and fractions 13-16 gave $5.8 \mathrm{mg}$ of $3^{\prime \prime}$-hydroxyisochamanetin (4). Subfractions $17-20$ were combined for further separation on a Sephadex column, also eluted with 1:1 $\mathrm{MeOH}-\mathrm{CH}_{2} \mathrm{Cl}_{2}$, resulting in 32 fractions of $\sim 1 \mathrm{~mL}$ each. TLC analysis also enabled the combination of fractions 15-23, which were then subjected to preparative HPLC, using 70:30 Milli Q water-methanol, to obtain gracidiol $(\mathbf{1}, 4.5 \mathrm{mg})$. Preparative HPLC of fractions 24-29, using the same conditions, gave three peaks, 
representing 7-hydroxy-6-hydromelodienone (10), (Z)-acetylmelodorinol (8), and (Z)-2'-hydroxyacetylmelodorinol (3). The combined fractions 8-10 from the initial column were subjected to gravity column chromatography, eluted with $50 \%$ EtOAc-i-hexane. This yielded 12 fractions, of which fraction 6 was purified further on a Sephadex column, $\mathrm{MeOH}-\mathrm{CH}_{2} \mathrm{Cl}_{2}$ (1:1), giving 32 fractions, of which fractions $10-18$ gave $75.7 \mathrm{mg}$ of $(Z)$-melodorinol (9), while fractions 29-32 yielded $1 \mathrm{mg}$ of 5,7-dihydroxy-8-(2,3dihydroxybenzyl)flavone (5). Fraction 11, obtained from the initial column, was separated over Sephadex by elution with 1:1 MeOH$\mathrm{CH}_{2} \mathrm{Cl}_{2}$, yielding 15 fractions. Fractions 9-11 contained complex, inseparable mixtures of compounds, which were not further analyzed, while fractions 12-14 were separated once again, as described above, yielding $186.5 \mathrm{mg}$ of 3 "-hydroxygracinol (6).

The root bark extract $(68.0 \mathrm{~g})$ was subjected to vacuum liquid chromatography under gradient elution (20\% EtOAc-petroleum ether to $10 \% \mathrm{MeOH}-\mathrm{EtOAc}$ ) to obtain 10 fractions of $\sim 500 \mathrm{~mL}$ each, which were analyzed with TLC and developed using EtOAcpetroleum ether at ratios of 2:8, 5:5, 7.5:2.5, and 9:1. Fraction 3, obtained at $50 \%$ EtOAc-petroleum ether, was further separated on a Sephadex column, as above, giving 22 fractions. Following TLC analysis, fractions 14 and 15 were combined and subjected to gravity column chromatography using an elution gradient from 30\% to $50 \%$ EtOAc- $i$-hexane, giving 45 fractions of $10 \mathrm{~mL}$ each. Fractions 44 and 45 contained complex, inseparable mixtures of compounds and were not further analyzed. Fraction 4 from the initial column, obtained using $50-75 \%$ EtOAc- $i$-hexane, was subjected to gravity column chromatography, using gradient elution from $40 \%$ to $75 \%$ EtOAc-ihexane, yielding pinocembrin $(11,36.7 \mathrm{mg})$. Fraction 6 , obtained from elution with $3 \% \mathrm{MeOH}-\mathrm{EtOAc}$, underwent successive separation on the Sephadex column $\left(1: 1 \mathrm{MeOH}-\mathrm{CH}_{2} \mathrm{Cl}_{2}\right)$ and silica gel column chromatography (75\% EtOAc-i-hexane), yielding $(Z)$ sphaerodiol $(7,2.1 \mathrm{mg}$ ). The polar fraction, 8 (obtained at $10 \%$ $\mathrm{MeOH}-\mathrm{EtOAc})$, gave (Z)-7-acetylsphaerodiol (2, $19.8 \mathrm{mg})$.

The crude methanol extract of the stem bark $(43.0 \mathrm{~g})$ was fractionated chromatographically and purified as described above, leading to the isolation of $(Z)-7$-acetylsphaerodol $(2,32.0 \mathrm{mg}), 3^{\prime \prime}$ hydroxygracinol $(6,89.0 \mathrm{mg}),(Z)$-sphaerodiol $(7,24.0 \mathrm{mg}),(Z)$ acetylmelodorinol $(8,63.0 \mathrm{mg}),(Z)$-melodorinol $(9,15.0 \mathrm{mg}), 5,7-$ dihydroxyflavone $(12,18.7 \mathrm{mg})$, chamanetin $(13,64.8 \mathrm{mg})$, isochamanetin $(14,23.6 \mathrm{mg})$, dichamanetin $(15,126.8 \mathrm{mg})$, and polycarpol $(16,18.0 \mathrm{mg})$.

Gracidiol (1): colorless oil; $[\alpha]^{20}{ }_{\mathrm{D}}+52.0(c 0.15, \mathrm{MeOH})$; ECD $\left(\mathrm{MeOH}, \lambda_{\mathrm{nm}}\left(\Delta \varepsilon ; \mathrm{M}^{-1} \mathrm{~cm}^{-1}\right)(+9.23)_{331} ;(-40.16)_{288} ;(+45.07)_{222}\right.$; $\mathrm{UV}\left(\mathrm{CHCl}_{3}\right) \lambda_{\max }(\log \varepsilon) 275$ (4.53), 230 (4.34), 215 (4.72) nm; IR $(\mathrm{KBr}) \nu_{\max } 3424,1634,1265,739 \mathrm{~cm}^{-1} ;{ }^{1} \mathrm{H}$ and ${ }^{13} \mathrm{C}$ NMR data, see Table 1; ESIMS $m / z$ 393.2 $[\mathrm{M}+\mathrm{Na}]^{+}$, 388.4, 371.3, 353.6, 329.6, 279.3, 249.5, 235.3, 223.4, 229.7, 205.2, 177.2, 149.5, 137.5, 131.1, 101.1; HRESIMS $[\mathrm{M}+\mathrm{H}]^{+} \mathrm{m} / z 371.1479$ (calcd for $\mathrm{C}_{21} \mathrm{H}_{23} \mathrm{O}_{6}$ 371.1495).

(Z)-7-Acetylsphaerodol (2): colorless oil; $[\alpha]^{20}{ }_{\mathrm{D}}+3.0$ (c 15.2, $\mathrm{MeOH})$; ECD $\left(\mathrm{MeOH}, \lambda_{\mathrm{nm}}\left(\Delta \varepsilon ; \mathrm{M}^{-1} \mathrm{~cm}^{-1}\right)(+2.20)_{389} ;(-2.77)_{361}\right.$; $(+0.60)_{286} ;(-4.20)_{251} ;(+4.15)_{212} ; \mathrm{UV}(\mathrm{MeOH}) \lambda_{\max }(\log \varepsilon) 270$ (4.41) nm; IR (KBr) $\nu_{\max } 3446,3056,1781,1743,1423,1265,110$, 940, $738 \mathrm{~cm}^{-1}$; ${ }^{1} \mathrm{H}$ and ${ }^{13} \mathrm{C}$ NMR data, see Table 3; ESIMS $\mathrm{m} / z 221.3$ $[\mathrm{M}+\mathrm{Na}]^{+}, 207.8,181.1,153.2,139.3,121.4,111.2,93.2,85.5,65.0 ;$ HRESIMS $[\mathrm{M}+\mathrm{H}]^{+} \mathrm{m} / z 199.0629$ (calcd for $\mathrm{C}_{9} \mathrm{H}_{11} \mathrm{O}_{5}$ 199.0606).

(Z)-2'-Hydroxyacetylmelodorinol (3): colorless oil; $[\alpha]^{20}+0.12(c$ 16.7, $\mathrm{MeOH}) ; \mathrm{UV}(\mathrm{MeOH}) \lambda_{\max }(\log \varepsilon) 240(2.89), 205(3.52) \mathrm{nm}$; IR $(\mathrm{KBr}) \nu_{\max } 3417,1639,1265,740 \mathrm{~cm}^{-1} ;{ }^{1} \mathrm{H}$ and ${ }^{13} \mathrm{C}$ NMR data see Table 2; ESIMS $\mathrm{m} / z$ 341.2 $[\mathrm{M}+\mathrm{Na}]$, 336.3, 284.7, 272.6, 259.4, 221.3, 213.1, 177.3, 183.3, 139.4, 149.4, 121.4; HRESIMS $[\mathrm{M}+\mathrm{H}]^{+}$ $m / z 319.0801$ (calcd for $\mathrm{C}_{16} \mathrm{H}_{15} \mathrm{O}_{7} 319.0818$ ).

3"-Hydroxyisochamanetin (4): white powder; mp $196-197{ }^{\circ} \mathrm{C}$; $[\alpha]^{20}{ }_{\mathrm{D}}-3.59$ (c 4.4, $\left.\mathrm{MeOH}\right) ; \mathrm{CD}\left(\mathrm{MeOH}, \lambda_{\mathrm{nm}}\left(\Delta \varepsilon ; \mathrm{M}^{-1} \mathrm{~cm}^{-1}\right)\right.$ $(-3.56)_{382} ;(+1.27)_{286} ;(-2.64)_{251} ;(+1.36)_{227} ; \mathrm{UV}(\mathrm{MeOH}) \lambda_{\max }$ $(\log \varepsilon) 320$ (4.72), 290 (4.79) nm; IR (KBr) $\nu_{\max } 3430.9,1641,1477$, 1255, $739 \mathrm{~cm}^{-1}$; ${ }^{1} \mathrm{H}$ and ${ }^{13} \mathrm{C}$ NMR data see Table 4; ESIMS $\mathrm{m} / \mathrm{z}$ $379.3[\mathrm{M}+\mathrm{H}]^{+}, 289.4,269.5,257.5,241.4,233.3,180.7,175.4,149.6$,
107.3, 91.2, 83.2, 86.2; HRESIMS $[\mathrm{M}+\mathrm{H}]^{+} \mathrm{m} / z 379.1171$ (calcd for $\left.\mathrm{C}_{22} \mathrm{H}_{19} \mathrm{O}_{6} 379.1182\right)$.

5,7-Dihydroxy-8-(2,3-dihydroxybenzyl)flavone (5): yellow powder; UV $(\mathrm{MeOH}) \lambda_{\max }(\log \varepsilon) 280(4.16) \mathrm{nm}$; IR (KBr) $\nu_{\max } 3430$, 1642, 1265, $740 \mathrm{~cm}^{-1} ;{ }^{1} \mathrm{H}$ and ${ }^{13} \mathrm{C}$ NMR data, see Table 5; ESIMS $m / z 377.5[\mathrm{M}+\mathrm{H}]^{+}, 376.5,267.0,149.4,111.5,99.1,74.1,69.3$; HRESIMS $[\mathrm{M}+\mathrm{H}]^{+} m / z 377.1012$ (calcd for $\mathrm{C}_{22} \mathrm{H}_{17} \mathrm{O}_{6} 377.1025$ ).

Antiplasmodial and Cytotoxicity Assays. Antiplasmodial activity was determined using a high-content imaging assay, as described previously. ${ }^{10,24}$ The cytotoxicity of the antiplasmodial compounds was evaluated against human embryonic kidney cells (HEK-293) following an established protocol. ${ }^{10,24}$ Human red blood cells for culture of $P$. falciparum were provided by the Australian Red Cross Blood Bank in accordance with their routine Material Transfer Agreement (MTA) for nonclinical blood product supply. These bioassay studies were approved by the Griffith University Biosafety and Human Ethics Committee (GU ref no. ESK/03/12/HREC; 03/ 08/11019).

Translation Inhibition Assay. Luciferase inhibition activity assays were performed following standard procedures described previously., ${ }^{9,10}$

\section{ASSOCIATED CONTENT}

\section{Supporting Information}

The Supporting Information is available free of charge at https://pubs.acs.org/doi/10.1021/acs.jnatprod.9b00721.

Structures and tables containing ${ }^{1} \mathrm{H}$ and ${ }^{13} \mathrm{C}$ NMR data for the known compounds 6-16;1D and 2D NMR spectra and HRESIMS for the new compounds 1-5 (PDF)

\section{AUTHOR INFORMATION}

\section{Corresponding Authors}

Stephen S. Nyandoro - Chemistry Department, College of Natural and Applied Sciences, University of Dar es Salaam, Dar es Salaam, Tanzania; Department of Chemistry and Molecular Biology, University of Gothenburg, SE-412 96 Gothenburg, Sweden; Phone: +255-754-206560; Email: nyandoro@ udsm.ac.tz

Máté Erdélyi - Department of Chemistry and Molecular Biology, University of Gothenburg, SE-412 96 Gothenburg, Sweden; Department of Chemistry - BMC, Uppsala University, SE-751 23 Uppsala, Sweden; o orcid.org/0000-0003-03595970; Phone: +46-18-4713810; Email: mate.erdelyi@ kemi.uu.se

\section{Authors}

Gasper Maeda - Chemistry Department, College of Natural and Applied Sciences, University of Dar es Salaam, Dar es Salaam, Tanzania; Department of Chemistry and Molecular Biology, University of Gothenburg, SE-41296 Gothenburg, Sweden

Joan J. E. Munissi - Chemistry Department, College of Natural and Applied Sciences, University of Dar es Salaam, Dar es Salaam, Tanzania

Sofia Lindblad - Department of Chemistry and Molecular Biology, University of Gothenburg, SE-412 96 Gothenburg, Sweden; Department of Chemistry - BMC, Uppsala University, SE-751 23 Uppsala, Sweden

Sandra Duffy - Discovery Biology, Griffith Institute for Drug Discovery, Griffith University, Nathan Q1d 4111, Australia

Jerry Pelletier - Department of Biochemistry, McGill University, Montreal, QC H3G 1Y6, Canada

Vicky M. Avery - Discovery Biology, Griffith Institute for Drug Discovery, Griffith University, Nathan Q1d 4111, Australia 
Complete contact information is available at:

https://pubs.acs.org/10.1021/acs.jnatprod.9b00721

\section{Notes}

The authors declare no competing financial interest. Original FIDs are available, open access, at Zenodo with DOI: 10.5281 /zenodo. 3355165 .

\section{ACKNOWLEDGMENTS}

The Swedish Research Council (2016-05857) and the Australian Research Council (VMA, grant no. LP120200557) are gratefully acknowledged for financial support. S.S.N. is grateful to the Swedish Institute for a postdoctoral research award (00045/2014). We thank Mr. Frank M. Mbago, curator at the Herbarium of the Department of Botany, University of Dar es Salaam, for locating and identifying the investigated plant species. We thank the Australian Red Cross Blood Bank for the supply of human blood for parasite culture. The Swedish NMR Centre is acknowledged for access to an 800 $\mathrm{MHz}$ spectrometer.

\section{REFERENCES}

(1) IUCN. The IUCN Red List of Threatened Species, 2009.

(2) Verdcourt, B. Flora of Tropical East Africa; Annoaceae, Vol. 5; Royal Botanic Gardens: Kew, Richmond, UK, 1971; p 131.

(3) Bick, I.; Preston, N. Aust. J. Chem. 1971, 24, 2187-2188.

(4) Jung, J.; Chang, C.-J.; Smith, D.; McLaughlin, J.; Pummangura, S.; Chaichantipyuth, C.; Patarapanich, C. J. Nat. Prod. 1991, 54, 500505.

(5) Jung, J.; Pummangura, S.; Chaichantipyuth, C.; Patarapanich, C.; Fanwick, P.; Chang, C.-J.; McLaughlin, J. Tetrahedron 1990, 46, $5043-5054$

(6) Tuchinda, P.; Udchachon, J.; Reutrakul, V.; Santisuk, T.; Taylor, W. C.; Farnsworth, N. R.; Pezzuto, J. M.; Kinghorn, A. D. Phytochemistry 1991, 30, 2685-2689.

(7) Momburi, S. W. New Natural Products and Other Constituents of Sphaerocornye gracilis spp. gracilis, M.Sc. Thesis, University of Dar es Salaam, Tanzania, 1998.

(8) Nkunya, M. H. Pure Appl. Chem. 2005, 77, 1943-1955.

(9) Novac, O.; Guenier, A. S.; Pelletier, J. Nucle. Acids Res. 2004, 32, 902-915.

(10) Nyandoro, S. S.; Munissi, J. J.; Gruhonjic, A.; Duffy, S.; Pan, F.; Puttreddy, R.; Holleran, J. P.; Fitzpatrick, P. A.; Pelletier, J.; Avery, V. M.; Rissanen, K.; Erdelyi, M. J. Nat. Prod. 2017, 80, 114-125.

(11) Samwel, S. M.; S, J. M.; Nkunya, M. H. H.; Irungu, B. N.; Moshi, M. J.; Moulton, B.; Luisi, B. S. Nat. Prod. Commun. 2007, 2, 737-741.

(12) Shen, C.; Chou, S.; Chou, C.; Hop, L. K. Tetrahedron: Asymmetry 1996, 7, 3141-3146.

(13) Hasan, C. M.; Healey, T. M.; Waterman, P. G.; Schwalbe, C. H. J. Chem. Soc., Perkin Trans. 1 1982, 2807-2812.

(14) Ching, A. Y. L. W.; T, S.; Sukari, M. A.; Lian, G. E. L.; Rahmani, M.; Khalid, K. Malays. J. Anal. Sci. 2007, 1, 154-159.

(15) Chavi, Y.; Siripit, P.; Bungon, S. Arch. Pharmacal Res. 2009, 32, $1179-1184$.

(16) Joshi, V.; Chamoli, R. Bull. Chem. Soc. Ethiop. 2010, 24, 467471.

(17) Nyandoro, S. S.; Munissi, J. J.; Gruhonjic, A.; Duffy, S.; Pan, F.; Puttreddy, R.; Holleran, J. P.; Fitzpatrick, P. A.; Pelletier, J.; Avery, V. M.; Rissanen, K.; Erdelyi, M. J. Nat. Prod. 2017, 80, 114-125.

(18) Pan, L.; Matthew, S.; Lantvit, D. D.; Zhang, X.; Ninh, T. N.; Chai, H.; Carcache de Blanco, E. J.; Soejarto, D. D.; Swanson, S. M.; Kinghorn, A. D. J. Nat. Prod. 2011, 74, 2193-2199.

(19) Slade, D.; Ferreira, D.; Marais, J. P. Phytochemistry 2005, 66, 2177-2215.

(20) Antus, S.; Baitzgacs, E.; Kajtar, J.; Snatzke, G.; Tokes, A. L. Liebigs Ann. Chem. 1994, 1994, 497-502.
(21) Achenbach, H.; Höhn, M.; Waibel, R.; Nkunya, M. H.; Jonker, S. A.; Muhie, S. Phytochemistry 1997, 44, 359-364.

(22) Holzhauser, S.; Freiwald, A.; Weise, C.; Multhaup, G.; Han, C. T.; Sauer, S. Angew. Chem., Int. Ed. 2013, 52, 5171-5174.

(23) Novac, O.; Guenier, A. S.; Pelletier, J. Nucl. Acid Res. 2004, 32, 902-915.

(24) Duffy, S.; Avery, V. M. Am. J. Trop. Med. Hyg. 2012, 86, 84-92. 